\title{
Increasing the Efficiency of Pollutants Removal from Municipal Wastewater Using Biological Filters
}

\begin{abstract}
MARIANA MINCU*, MARIA IULIANA MARCUS, MIHAELA ANDREEA MITIU, NATALIA SIMONA RAISCHI
National Institute for Research and Development in Environmental Protection, 294, Splaiul Independentei, 060031, Bucharest, Romania

Biological filters are wastewater treatment systems that contain a granular filling material, which form an active biological film that contribute to the biooxidation of impurities from the wastewater. Recent research in the field aimed to improve the classical treatment facilities with aerobic fixed film by using inexpensive and easily accessible materials as filterable loading. Experiments have been carried out on biological filters loaded with volcanic tuff, with a diameter between $20-100 \mathrm{~mm}$, supplied with municipal wastewater from primary settling. The biological filtration efficiency has been etablished throughout the continuous functioning of the experimental installation by physico-chemical water analysis. The analyzed indicators have been the ones stipulated by the legislation in force, namely: $\mathrm{pH}$, chemical oxygen demand (COD), biochemical oxygen demand $\left(B O D_{5}\right)$, total suspended matter (TS), total nitrogen (TN), total phosphorus (TP), etc. The analysed wastewater samples have been average samples. The treatment efficiency have been calculated in various hypotheses, depending on the: installation capacity, hydraulic loading, organic loading.
\end{abstract}

Keywords: biological filters, wastewater, volcanic tuff, treatment efficiency

Ensuring surface water quality conditions can be achieved through an appropriate wastewater treatment plant, thus preventing the possible negative effects on the natural receptors [1-5]. The economic crisis has increased the interest in energy efficiency due to its ability to reduce costs as a result of the reduction in energy consumption $[6,7]$. Wastewater treatment in biofilters is a treatment process in which the culture of microorganisms is developed on a biologically inert support [8]. Biological filters as sewage treatment plants, contain a granular material filler (gravel, slag, coke, ceramic material, plastic, etc.), on which is formed a biological film that contribute to biooxidation of some pollutants from wastewater [9]. Processes by which impurities are converted into biomass and metabolites are similar to those that take place in treatment with activated sludge $[10,11]$. Current knowledge of microbiology and biochemistry of wastewater treatment processes, taking place in biological filters, allow a better understanding and design of biological filters. The wastewater that containing degradable pollutents is applied on top of the filtering layer of biological filter.

Wastewater passes in counter current with air, through the granular filler material on which develops an organic film and leaves the plant. Since a single crossing of the filler material is sometimes not sufficient to ensure the effectiveness of treatment desired, the effluent is recycled. In these circumstances, it is done gradually a biological organisms community, in the form of a biological pelicula and serves to the oxidation of pollutants present in the form of degradable substrate in wastewater. As a result of the removal of impurities the biological film, grows and emerges on the stuffing from time to time (the phenomenon of moulting) $[12,13]$. The peeled film is removed from the treated effluent by decanting; therefore biological filters are followed by secondary clarifiers. Similar biological wastewater treatment with activated sludge, in case of biological filter the essential role in treatment have bacteria that form the basic food chain [14]. The removal of organic substances dissolved in water is made through their adsorption to bacterial cell surface [15]. Heterotrophic bacteria and fungi perform the primary oxidation of pollutants, while autotrophic bacteria (which requires only carbon dioxide and an inorganic source of energy for cell growth) continue this oxidation process, being represented mainly by Nitrosomonas (which oxidize ammonium nitrites) and Nitrobacter (which oxidizes nitrites to nitrates) $[16,17]$. Green algae and bacteria are found only on the upper part of the filter or immediately below it. In case of a biological filter with usual load the ciliates are present in the same proportion as the mushrooms; they consume free bacteria, in suspension state and thus clear the effluent. Conditions offered by the biological filter varies with their height, thus, more evolved life forms - worms, insects, etc. - along with the algae, grow more frequently in the upper or only on top, in light (algae). In general, for designing biological filters, are chosen the dimensioning parameters referred to in the literature, which may range, depending on the type of biological filter.

\section{Experimental part}

The laboratory experiments have been carried out on biological tower filters and biological filters with high charge. Installation flow has been: $1.0 \mathrm{~L} / \mathrm{s}$, of which $0.2 \mathrm{~L} /$ $\mathrm{s}$ for high line loading and $0.8 \mathrm{~L} / \mathrm{s}$ for tower line. Depending on the size and degree of purification of the granules, as well as nature and height of the filter layer, the distribution of wastewater and ventilation, there are three models for each tower type or high-loading filters: model filled with microcellular tuff; model filled with porous medium tuff; model filled with crushed basalt.

The grain of the filter material is made according to the usual rules, namely: superficial layer (distribution) with thickness $h=20 \mathrm{~cm}, \varnothing=20 \mathrm{~mm}-40 \mathrm{~mm}$; working layer $(\varnothing=40 \mathrm{~mm}-60 \mathrm{~mm}$ ); lower layer (supportive) with thickness $h=50 \mathrm{~cm}-60 \mathrm{~cm}, \varnothing=60 \mathrm{~mm}-120 \mathrm{~mm}$.

The superficial hydraulic loadings with which the experimental models have been fed, are the ones recommended for these types of installations, about 10 $\mathrm{m}^{3} / \mathrm{m}^{2} \times \mathrm{h}$ for biological tower filters and about $1 \mathrm{~m}^{3} / \mathrm{m}^{2} \times \mathrm{h}$ for high biological loading filters. It was intended to place the filter materials under the most severe operating

*email; mincu_mariana@yahoo.com 
conditions, in cold weather, when the possibility of freezing of the filters and thus the degradation of the filter material is much higher. In order to investigate the biological treatment process, the models have been charged with municipal wastewater from primary settling and the biological filtering efficiency has been monitored throughout the continuous functioning of the experimental installation by physico-chemical water analysis.

The monitored indicators have been: air temperature, water temperature, $\mathrm{pH}$, chemical oxygen demand (COD), biochemical oxygen demand $\left(\mathrm{BOD}_{5}\right)$, total suspended solid (TSS), total nitrogen (TN), total phosphorus (TP), nitrites $\left(\mathrm{NO}_{2}\right)$, ammonia $\left(\mathrm{NH}_{3}\right)$, sediments. The analysed wastewater samples have been average samples taken at intervals corresponding to each steps of purification. The characterization of wastewater during the experiments is presented in table 1.

Table 1

CHARACTERIZATION OF WASTEWATER DURING THE EXPERIMENTS

\begin{tabular}{|c|c|c|}
\hline Indicator & Unit & Range of values \\
\hline Water temperature & ${ }^{\text {UC }}$ & $10.5 \div 28$ \\
\hline $\mathrm{pH}$ & $\mathrm{pH}$ units & $6.0 \div 8.0$ \\
\hline $\mathrm{COD}$ & $\mathrm{mg} \mathrm{O} / \mathrm{dm}^{3}$ & $62 \div 203$ \\
\hline $\mathrm{BOD} 5$ & $\mathrm{mg} / \mathrm{dm}^{3}$ & $25 \div 63$ \\
\hline $\mathrm{TSS}$ & $\mathrm{mg} / \mathrm{dm}^{3}$ & $60 \div 246$ \\
\hline $\mathrm{TN}$ & $\mathrm{mg} \mathrm{N} / \mathrm{dm}^{3}$ & $9.3 \div 104.8$ \\
\hline $\mathrm{TP}$ & $\mathrm{mg} \mathrm{P} / \mathrm{dm}^{3}$ & $0.1 \div 1.5$ \\
\hline $\mathrm{NO}_{2}^{-}$ & $\mathrm{mg} \mathrm{N} / \mathrm{dm}^{3}$ & $0.018 \div 3.6$ \\
\hline $\mathrm{NH}_{3}$ & $\mathrm{mg} \mathrm{N} / \mathrm{dm}^{3}$ & $5.4 \div 11.3$ \\
\hline Sediments & $\mathrm{cm}^{3} / \mathrm{dm}^{3}$ & $0.9 \div 3.0$ \\
\hline
\end{tabular}

\section{Results and discussions}

During water sampling, hydraulic loadings $\left(\mathrm{H}_{3}\right)$ of biological filters tower type had values in the range of 5.08$15.26 \mathrm{~m}^{3} / \mathrm{m}^{2} \times \mathrm{xh}$, at organic loads between $39.03-126.18 \mathrm{~g}$ $\mathrm{BOD}_{5} / \mathrm{m}^{3} \mathrm{xh}$. Hydraulic loadings $\left(\mathrm{H}_{1}\right)$ of high loading biological filters had values in the range of $0.46-2.29 \mathrm{~m}^{3} /$ $\mathrm{m}^{2} \mathrm{xh}$, at organic loads between 10.66-32.92 $\mathrm{g} \mathrm{BOD}_{5} / \mathrm{m}^{3} \mathrm{xh}$.
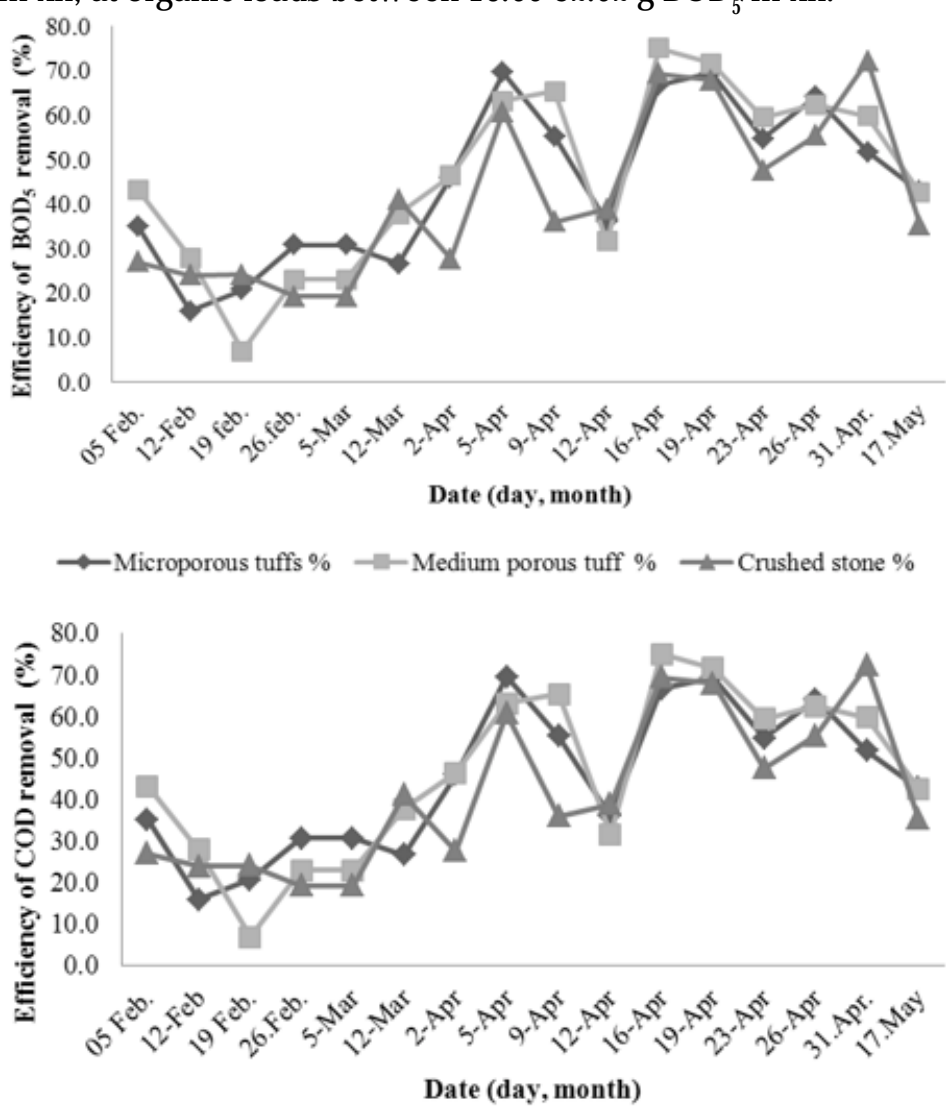

The treatment efficiencies have been satisfactory for all specific wastewater treatment indicators, considering that the raw wastewater was generally relatively low loaded.

The results are presented in figures 1, 2 and 3.

In higher temperatures periods, the treatment efficiencies have been considerably higher, reaching values of $72-75 \% \mathrm{BOD}_{5}$ for biological tower filters at optimal specific hydraulic loading $\mathrm{H}_{\mathrm{b}}=10.18 \mathrm{~m}^{3} / \mathrm{m}^{2} \mathrm{xh}$ and $62-72 \%$ $\mathrm{BOD}_{5}$ for high loading biological filters at optimal specific hydraulic loading $\mathrm{H}_{\mathrm{L}}=0.92 \mathrm{~m}^{3} / \mathrm{m}^{2} \times \mathrm{h}$. The development of the biological film has been normal, although, the air temperature has been low in the first period of experiments, oscillating in the range $14.2^{-38^{\circ}} \mathrm{C}$. This situation is due to the fact that the temperature of the raw water did not drop below $9.5^{\circ} \mathrm{C}$ and reached up to $28^{\circ} \mathrm{C}$ in the summer period. At 7-10 days after beginning of experiments, the presence of a well-developed biological film has been observed on both tuff and stone granules. A more advanced film development has been observed on volcanic tuffs compared to crushed stone, a situation also reflected by the results of physico-chemical analyzes, which revealed during this period more efficient purification of volcanic tuffs.

By analyzing average values of technological parameters from experimental installations, it can be concluded that, the obtained values are very similar for all three types of tested filterable loading. However, on both the high loading biological filters (fig. 4), and especially on the biological tower filters (fig. 5), where differences are a little bit more pronounced, the highest values come from the average porous tuff, followed by microporous tuff, respectively of crushed stone (fig. 6).

At the high loading biological filters and specific hydraulic loading $\mathrm{H}_{\mathrm{L}}=0.92 \mathrm{~m}^{3} / \mathrm{m}^{2} \times \mathrm{h}$ or hydraulic loading $H_{L}=2.29 \mathrm{~m}^{3} / \mathrm{m}^{2} \times h$, oxidations achieved had higher values
Fig. 1. Removal efficiency of $\mathrm{BOD}_{5}$ with biological tower filters
Fig. 2. Removal efficiency of COD with high loading biological filters 

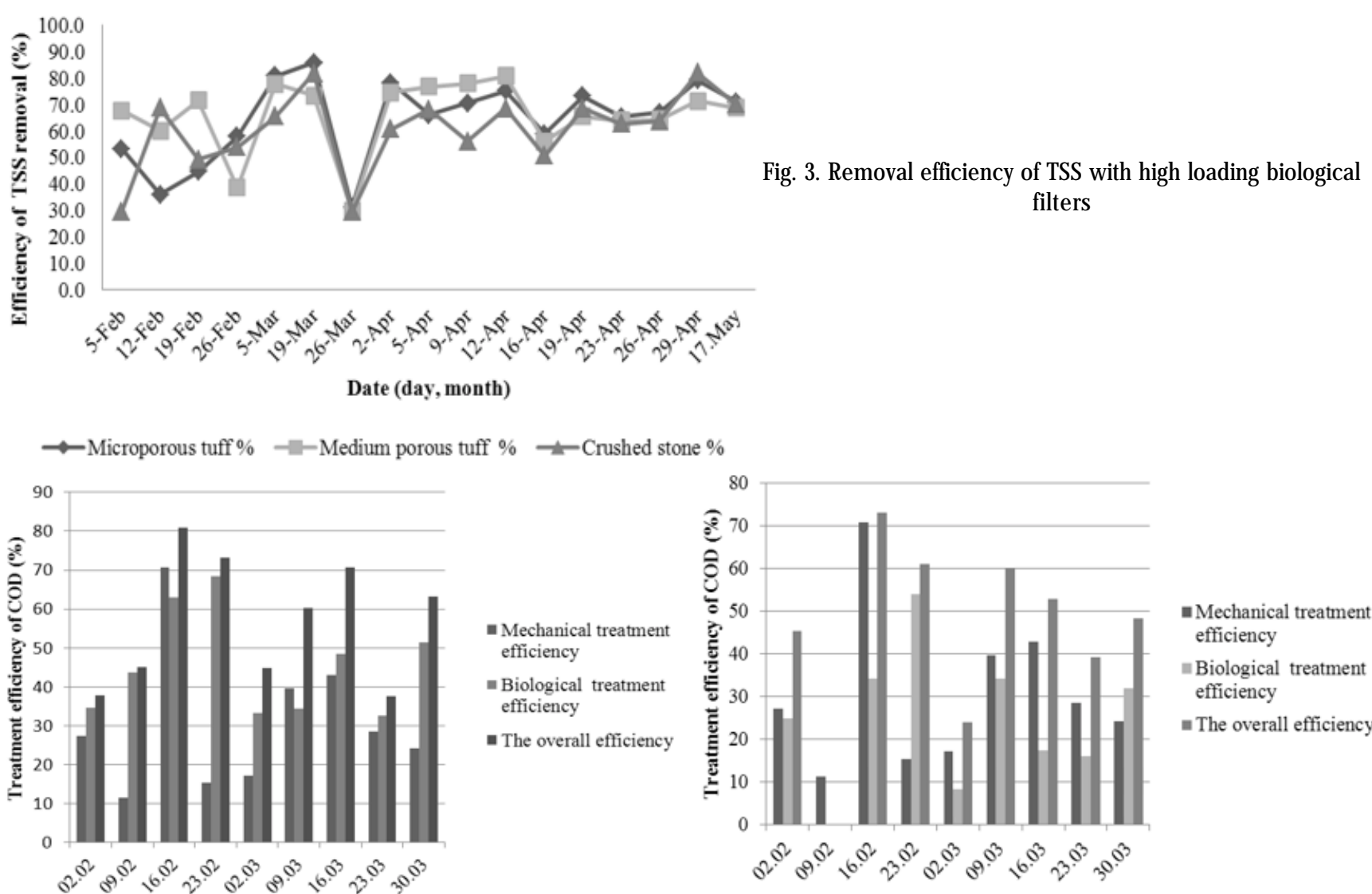

Fig. 4. Registered efficiency for high loading biological filters with porous tuff

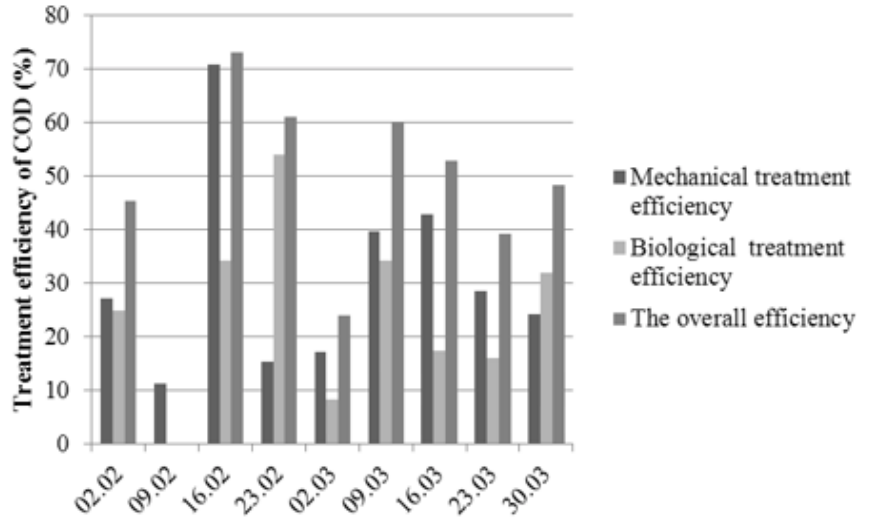

Fig. 5. Registered efficiency for biological tower filters with porous tuff

Fig. 6. Registered efficiency for the high loading biological filters with crushed stone

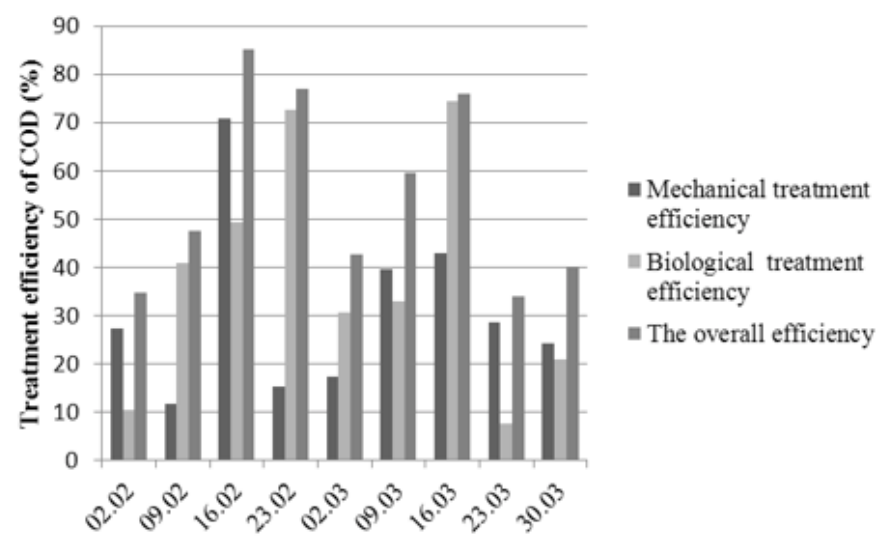

\begin{tabular}{|c|c|c|c|}
\hline $\begin{array}{c}\text { Specific hydraulic } \\
\text { loadings }\left(\mathrm{m}^{3} / \mathrm{m}^{2} \mathrm{xh}\right)\end{array}$ & \multicolumn{3}{|c|}{$\begin{array}{c}\text { Removal efficiency of } \mathrm{BOD}_{5} \text {, obtained for high loading } \\
\text { biological filters }\end{array}$} \\
\hline & $\begin{array}{c}\text { Microporous tuff } \\
(\%)\end{array}$ & $\begin{array}{c}\text { Medium porous } \\
(\%)\end{array}$ & $\begin{array}{c}\text { Crushed stone } \\
\%)\end{array}$ \\
\hline 0.46 & $50-66$ & $46-64$ & $36-40$ \\
\hline 0.92 & $15-67$ & $15-68$ & $15-72$ \\
\hline 2.29 & $51-52$ & $41-69$ & $31-61$ \\
\hline
\end{tabular}

Table 2

REMOVAL EFFICIENCY OF BOD, OBTAINED FOR HIGH LOADING BIOLOGICAL FILTERS

for biological filters with microporous tuff and crushed stone. Results are presented in table 2.

At the high loading biological filters and hydraulic loading $\mathrm{H}_{1}=0.92 \mathrm{~m}^{3} / \mathrm{m}^{2} \mathrm{xh}$, the removal efficiency of $\mathrm{BOD}_{5}$ has been $15-67 \%$ for microporous tuff, $15-68 \%$ for medium porous tuff and $15-72 \%$ for crushed stone.

For $H_{1}=2.29 \mathrm{~m}^{3} / \mathrm{m}^{2} \mathrm{xh}$ the removal efficiency of $\mathrm{BOD}_{5}$ has been $51-52 \%$ for microporous tuff, $41-69 \%$ for medium porous tuff and $31-61 \%$ for crushed stone. At a hydraulic loading of $0.46 \mathrm{~m}^{3} / \mathrm{m}^{2} \mathrm{xh}$, the high loading biological filters had removal efficiency of $B O D_{5}$ between $50-66 \%$ for microporous tuff, $46-64 \%$ for medium porous tuff and 36$40 \%$ for crushed stone.

Regarding the biological tower filters, removal efficiency of $\mathrm{BOD}_{5}$, oxidations achieved had higher values for biologicall filters with medium porous tuff at $\mathrm{H}_{\mathrm{b}}=10.18 \mathrm{~m}^{3} /$ $\mathrm{m}^{2} \mathrm{xh}$ and $H_{L}=15.26 \mathrm{~m}^{3} / \mathrm{m}^{2} \mathrm{xh}$. Results are presented in table 3.

The removal efficiency of $\mathrm{CBO}_{5}$ in biological tower filters with $\mathrm{H}_{\mathrm{L}}=10.18 \mathrm{~m}^{3} / \mathrm{m}^{2} \mathrm{xh}$ had values in range of $13-72 \%$ for microporous tuff, $7-75 \%$ for medium porous tuff and $12-$ $74 \%$ for crushed stone. At $H_{=}=15.26 \mathrm{~m}^{3} / \mathrm{m}^{2} \times \mathrm{xh}$, the removal efficiency of $\mathrm{CBO}_{5}$ ranged between 55-64\% for microporous tuff, $60-62 \%$ for medium porous tuff and $48-55 \%$ for crushed stone. For $\mathrm{H}_{\mathrm{L}}=5.08 \mathrm{~m}^{3} / \mathrm{m}^{2} \times \mathrm{xh}$ the removal efficiency of $\mathrm{CBO}_{5}$ had values in range of $43-52 \%$ for microporous tuff, 43 $60 \%$ for medium porous tuff and $35-72 \%$ for crushed stone. 


\begin{tabular}{|c|c|c|c|}
\hline $\begin{array}{l}\text { Specific hydraulic } \\
\text { loading }\left(\mathrm{m}^{3} / \mathrm{m}^{2} \mathrm{xh}\right)\end{array}$ & \multicolumn{3}{|c|}{$\begin{array}{l}\text { Removal efficiency of } \mathrm{BOD}_{s, \text { obtained for biological }} \\
\text { tower filters }\end{array}$} \\
\hline & $\begin{array}{l}\text { Microporous tuff } \\
(\%)\end{array}$ & $\begin{array}{l}\text { Medium porous } \\
(\%)\end{array}$ & $\begin{array}{l}\text { Crushed stone } \\
\text { (\%) }\end{array}$ \\
\hline 5.08 & $3-52$ & $43-60$ & $35-72$ \\
\hline 10.18 & $13-72$ & 7.75 & $12-74$ \\
\hline 15.26 & $55-64$ & $60-62$ & $48-55$ \\
\hline
\end{tabular}

Table 3

REMOVAL EFFICIENCY OF BOD ${ }_{5}$, OBTAINED FOR BIOLOGICAL TOWER FILTERS

\section{Conclusions}

The experimental results for treatment installations equipped with aerobic film (biological tower filters and high loading biological filters) and operated with municipal wastewater have showed, through the technological parameters performed values and biological observations on the fixed film, that they are very closed for all three types of tested filter loadings. Wastewater treatment efficiency had satisfactory values for all specific indicators, also considering the fact that the raw water did not have a high load. Taking into account the experimental results, it is considered that the use of additional biological filters with volcanic tuff material loading in municipal wastewater treatment plants, can determine an increase in the treatment efficiency of these types of waters.

\section{References}

1. QASIM, M., SHAREEFDEEN, Z., Advances in Chemical Engineering and Science, no 3, 2013, p.57

2. YONGZHI CHENA, B., BAIKUN LI C., LIU YEA, YONGZHEN P., Biochemical Engineering J ournal 93, 2015, p. 235

3. DEAK, GY., DAESCU, V., HOLBAN, E., MARINESCU, P., TANASE, G. S. CSERGO, R., DAESCU, A. I., GAMAN, S., J ournal of Environmental Protection and Ecology, 16, no 1, 2015, p. 304

4. VIJAY KUMAR, K., SRIDEVI, V., HARSHA, N., CHANDANA LAKSHMI, M.V.V., RANI, K., International J ournal of Application or Innovation in Engineering \& Management (IJAIEM), 2, no 9, 2013, p. 226

5. ALMSTRAND R1., LYDMARK P., SÖRENSSON F., HERMANSSON M., Bioresour Technol. 102 (17), 2011, p. 7685
6. RESETAR-DEAC, A. M., DEAK, GY., MARINESCU, P., DAESCU, V., HOLBAN, E., CSERGO, R., TANASE, S. G., GAMAN, S., J ournal of Environmental Protection and Ecology, 16, no 1, 2015, p. 183

7. RADA, E. C., RABONI, M., TORRETTA, V., COPELLI, S., RAGAZZI, M., CARUSON, P., ISTRATE I. A., Rev. Chim. (Bucharest), 65, no. 1, 2014, p. 68

8. SABBAH, I., BARANSI, K., MASSALHA, N., DAWASA, A., SAADI, I., NEJ IDAT, A., Ecological Engineering, 53, 2013, p. 354

9. STANILOIU C., FLORESCU C., POPESCU V., Rev. Chim. (Bucharest), 64, no. 12, 2013, p.1477

10. NEGULESCU, M.,Epurarea apelor uzate industriale, Editura Tehnica, Bucuresti, 1978

11. ROTHER, E. and CORNEL, P, Water Science and Technology, 50 no 6, 2004, p. 131

12.DURGANANDA SINGH CHAUDHARY, SARAVANAMUTHU VIGNESWARAN, HUU-HAO NHO, WANG GEUN SHIM AND HEE MOO, Chem. Eng.. 20, no 6, 2003, p. 1054

13. HALIS SIMSEK A., MURTHY KASI A, B., TANUSH WADHAWAN A., CHRISTOPHER BYE C., MARK BLONIGEN D., KHAN E., 46 , 2012, p. 5115

14. MINCU M., TOCIU C., 2011, ECOTERRA, J ournal of Environmental Research and Protection, no. 26, p.73

15. GHEORGHE, C. G., PANTEA, O., MATEI, V., BOMBOS, D., BORCEA, A.-F., Rev. Chim. (Bucharest) 62, no.6, 2011, p.655

16. STOENICA M., BUZATU P., LAVRIC V., Rev. Chim. (Bucharest) 63, no.3, 2012, p.298

17. *** EC Directive 271, Council Directive 91/271/EEC of 21 May 1991 concerning urban waste-water treatment, Official J ournal of European Communities, L135, 1997, p 40

Manuscript received: 25.09 .2017 